of Technology since 1921. Dr. Babcock is at present assistant director of the Observatories. He has been a member of the Observatories' staff since 1946, having previously been associated with Lick Observatory, Yerkes and McDonald Observatories, the Radiation Laboratory at Massachusetts Institute of Technology and California Institute of Technology. The Observatories have a staff of sixteen astronomers. Their excellent facilities, which are used by visiting astronomers from all over the world, consist of: the world's largest telescope - the 200-in. Hale reflector-and the 48- and 18-in. Schmidt telescopes on Palomar Mountain; the 100-in. Hooker reflector, a 60 -in reflector, and three solar telescopes on Mount Wilson

\section{Tne Royal College of Science and Technology, Glasgow: Visiting Professorships}

A NEW form of visiting professorship has been instituted by the Royal College of Science and Technology, Glasgow, aimed at establishing closer links between the College and national and industrial research laboratories. As well as encouraging intimate collaboration between staff, the posts should lead to wider expert use of the facilities of both the College and external laboratories. The first five appointments are all senior staff of the National Engineering Laboratory (Department of Scientific and Industrial Research) at East Kilbride. Visiting professors will assume some of the responsibility for the supervision of research work engaging College staff and postgraduate students, particularly those centred at the research institutions. They will assume likewise, on behalf of the College and in collaboration with College staff, certain duties of a supervisory nature in respect of the research work of members of staff of such major institutions, particularly where such work could qualify for a higher degree, and they will provide special lectures or series of lectures.

Appointments will be for a period of up to five years in the first instance. The National Engineering Laboratory staff appointed to be the first visiting professors are: Dr. D. G. Sopwith, director of the Laboratory; F. D. Penny, deputy director; Dr. C. Timms, superintendent of the Machinery Group; Dr. L. Grunberg, superintendent of the Fluids Group; Dr. C. E. Phillips, superintendent of the Materials Group.

\section{Opportunities for Research in Tropical Countries of} the British Commonwealth

Sir Joseph Hutchinson, Drapers professor of agriculture, University of Cambridge, has written to the Editor of Nature pointing out the opportunities which now exist for work towards higher degrees in the young universities of the tropical members of the British Commonwealth. "For example, at Makerere College in Uganda, which will shortly become a constituent college of the new University of East Africa, new statutes will include provision for degrecs of M.A., M.Sc., and Ph.D., on the pattern common in universities in Britain. The range of unsolved problems on which studies are urgently needed is far wider in these tropical territories than in Britain, and the laboratory facilities in their young universities compare favourably with those enjoyed by research students in Britain. Moreover, library resources are good, though, of course, not so comprehensive as in Britain.

"The young universities have reached a stage at which, for their own intellectual progress, they need to develop graduate studies such as are commonly associated with work for the Ph.D. degree. At the same time, the attainment of independence has added urgency to the demand for their graduates to enter the public service and the rapidly developing commerce of the countries in which they are situated. For this roason, very few local graduates are likely to stay on for postgraduate study, and graduates from Britain would be particularly welcome.
"The opportunities for research in biology, social science, medicine, agriculture, geology, economics and geography are doubtless the most attractive, since the interest and importance of these subjects are so great in all underdeveloped countries, but the claims of education, English (as an international language) and history are great. Courses are also offered in subjects directly relevant to African conditions, such as the M.A. in African studies just announced by Makerere College. Some, but not many, Commonwealth Scholarships are offered by these countries, and at least two foundations have given grants for postgraduate work in overseas universities".

\section{M.R.C. Environmental Physiology Research Unit}

THE Medical Research Council's Climate and Working Efficiency Research Unit at Oxford is being transferred to the London School of Hygiene and Tropical Medicine. The Unit will be renamed the Environmental Physiology Research Unit, and will continue to investigate the efficient functioning of man in relation to environment, with particular reference to adaptation to hot and cold environments. Following the retirement of Sir Wilfrid le Gros Clark from the chair of human anatomy in the University of Oxford and honorary directorship of the Unit, Dr. J. S. Weiner, formerly honorary assistant director and reader in physical anthropology at that University, has been appointed director.

\section{Allowances and Taxation Relief for Scientific Research}

At the Committee Stage of the Finance Bill in the House of Commons on May 21, when an amendment was moved to ensure that capital expenditure on pilot plants for the application of scientific research qualified for the scientific research allowance, the Financial Secretary to the Treasury, Mr. A. Barber, assured the House that, under Clause 36 as it already stood, relief would be given for capital expenditure both in original research and in the applica. tion of known scientific principles in a new field. The explanatory notes issued by the Board of Inland Revenue read: "Capital expenditure incurred by a trader on scientific research related to his trade . . . for example, on the provision of laboratories pilot plant or other equipment is allowable for Income Tax purposes by five annual instalments", and Mr. Barber said that the latter position was being improved. When pressed, Mr. Barber quoted from the speech of the Chancellor of the Exchequer when the allowance was introduced in 1944. A.fter a reference to the pilot-plant stage where laboratory results are tried out experimentally on a larger seale and to the real difficulty of translating the skill of the research worker and the artificial conditions in which he may have worked into terms of large-scale production, the Chancellor described his proposals as a "comprehensive attempt to relieve from taxation altogether funds devoted by industry to the support of fundamental research, to the translation of laboratory research to production, and to the full-scale development of the product". Scientific research was defined in the Income Tax Act, 1952, as "any activities in the fields of natural or applied science for the extension of knowledge". Mr. Barber undertook to look into any particular difficulty that might have arisen. The Amendment was defeated by 224 votes to 169 .

\section{Management Education in Britain}

In the House of Lords on May 23, the Minister for Science, Lord Hailsham, said, in reply to a question, that developments in management studies were taking place in many univorsities. In conjunction with the Foundation for Management Education, the University Grants Committee had examined proposals for a further major development and 9 universities were to be givon spocial financial help to enable them to expand their activities in this field. The cost of these developments was expected to rise to about $£ 100,000$ a year by $1966-67$ and would be shared botween the Foundation and the Government; 